\title{
Polish energy security in the oil sector
}

\author{
Tadeusz Olkuski ${ }^{1, *}$, Adam Szurlej ${ }^{2}$, Barbara Tora ${ }^{3}$, Miłosz Karpiński ${ }^{4}$ \\ ${ }^{1}$ AGH University of Science and Technology, the Faculty of Energy and Fuels, Poland \\ ${ }^{2}$ AGH University of Science and Technology, the Faculty of Drilling, Oil and Gas, Poland \\ ${ }^{3}$ AGH University of Science and Technology, the Faculty of Mining and Geoengineering, Poland \\ ${ }^{4}$ International Energy Agency, Paris, France
}

\begin{abstract}
Almost all crude oil used in Poland is imported. The domestic production meets less than $4 \%$ of needs; therefore, to ensure the security of supplies, Poland relies heavily on imports. It is worth mentioning, however, that Poland has crude oil resources - oil fields are located in the Carpathians, Polish Lowlands, and in the economic zone of the Baltic Sea. For years, crude oil is imported mainly from the East, however, a significant change in this approach, leading to an increase in seaborne oil supplies, has been observed in recent years. In 2017, 77.3\% of crude oil was imported from Russia, while the rest was supplied from Saudi Arabia, Iraq, Iran, Norway, and Kazakhstan. Increasing the diversification of supplies is, of course, a very positive phenomenon, because it allows reducing the dependence on one supplier, which is beneficial from the point of view of energy security. Taking into account a high dependence on oil imports, the article also discusses important factors affecting the global oil market: low investment in the upstream sector, a drastic decline in oil production in Venezuela, the impact of the U.S. embargo on Iran, or depleting oil reserves.
\end{abstract}

\section{Introduction}

Crude oil is the fuel which has contributed to the development of civilization in an unprecedented way. Today it is difficult to imagine everyday life without oil and petroleum products. A landmark date for the oil sector was July 31, 1853: the kerosene lamp designed by Ignacy Łukasiewicz was used for the first time. The light from this lamp was used during the operation in Lviv. A year later, the crude oil mine in Bóbrka near Krosno was commissioned. Crude oil is, and will continue to be in the future, one of the primary energy sources. After the oil crises in the 1970s, a move away from using crude oil in the electrical power industry has been observed. Currently, attempts are being made to introduce electric cars; the use of renewable energy sources is also being developed. These actions result in a decrease in the demand for crude oil. However, crude oil, followed by coal and gas, remained the most consumed of primary energy source. Both the Current Policies and New Policies scenarios, developed by the International Energy Agency in the last year, assume that the demand for crude oil will grow. According to the Sustainable Development

\footnotetext{
* Corresponding author: olkuski@agh.edu.pl
} 
scenario, the demand for oil will be maintained at the current level, to rapidly decrease after 2025, mainly due to the introduction of electric cars. Meanwhile, the demand for highquality chemicals will increase by as much as 60\% in the years 2016-2040 [1]. In the years 2000-2017, a more than 50\% increase in oil consumption in Poland has been reported. In the same period the consumption in the EU decreased by about $10 \%$. According to the forecast until 2030, the upward trend in the demand for crude oil will be maintained. According to [2] this trend will last until 2050. In the case of [3] the expected demand for crude oil is completely different. A gradual decrease in demand from 2025 to 2050 is expected. This will be related to better fuel efficiency and the introduction of hybrid cars.

Other scenarios are presented in the report prepared by the Polish Organization of Oil Industry and Trade [4]. It presents the three liquid fuel demand scenarios until 2025 (Fig. 1). These are: baseline, optimistic, and pessimistic scenarios.

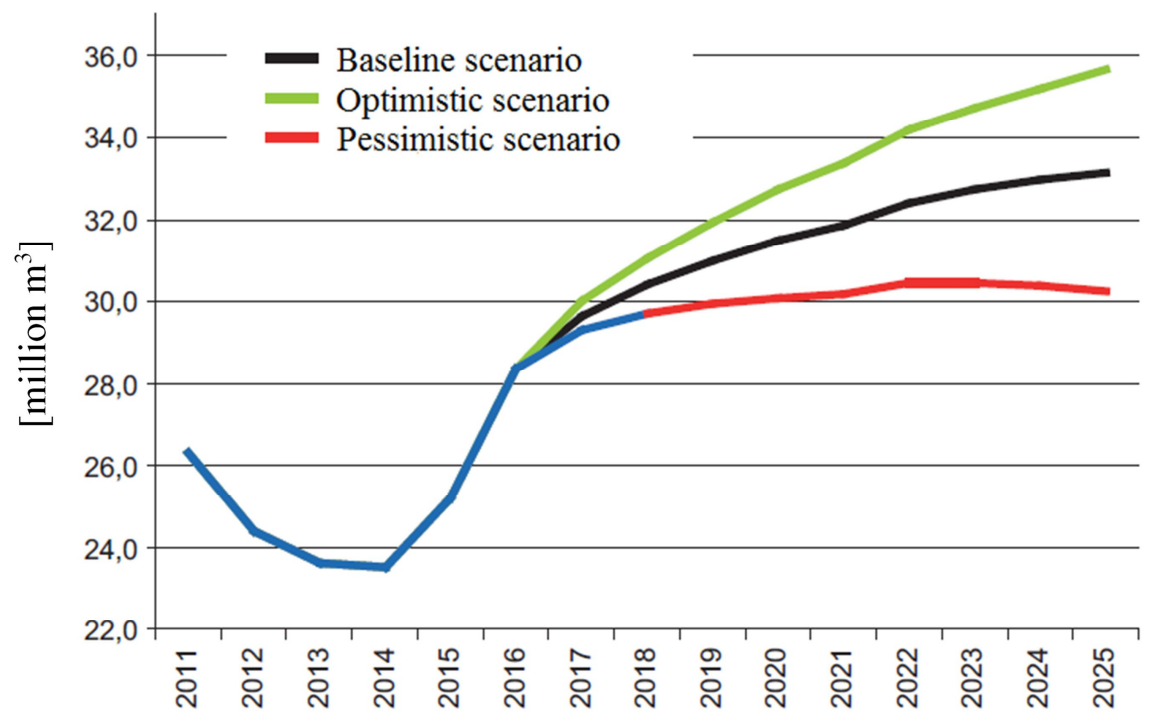

Fig. 1. Scenarios of demand for liquid fuels in the years 2011-2025 Source: [4]

The baseline scenario takes into account the current decrease in prices of liquid fuels and assumes that this will continue for two or three years. However, the demand for fuels in Poland should increase both in the base and optimistic scenarios. In the latter scenario, the VAT reduction and the reduction of the gray zone were assumed. The optimistic scenario adopted similar assumptions as the base scenario but also assumed an effective use of EU funds in the years 2014-2020 and thus the economic development and an increase in the income and mobility of the society. According to the optimistic scenario, the domestic demand for liquid fuels by 2025 will amount to 29 million $\mathrm{m}^{3}$ [4]. According to the authors of the report, the baseline scenario seems most likely.

\section{Basics of oil economy in Poland}

Table 1 presents oil resources in Poland broken down into exploitable resources (anticipated economic and sub-economic resources) and industrial resources as of December 31, 2017. The group of balance resources includes resources $\mathrm{A}+\mathrm{B}$ and $\mathrm{C}$ (Categories of recognition of solid minerals from the best (A) to the worst (D)). 
Table 1. Oil resources in Poland, thousand tons

\begin{tabular}{|c|c|c|c|c|c|}
\hline \multirow{3}{*}{$\begin{array}{l}\text { The number } \\
\text { of deposits }\end{array}$} & \multicolumn{4}{|c|}{ Reserves } & \multirow{3}{*}{$\begin{array}{l}\text { Industria } \\
\text { resources }\end{array}$} \\
\hline & \multicolumn{3}{|c|}{$\begin{array}{l}\text { Anticipated economic resources } \\
\text { (,,balance resources”) }\end{array}$} & \multirow{2}{*}{$\begin{array}{l}\text { Anticipated sub- } \\
\text { economic resources } \\
\text { (,sub-balance } \\
\text { resources”) }\end{array}$} & \\
\hline & Total & $A+B$ & $\mathrm{C}$ & & \\
\hline 86 & 23598.46 & 14660.23 & 8938.23 & 395.34 & 14482.15 \\
\hline
\end{tabular}

Source: [5]

In 2017 there were 86 documented oil fields in Poland, 29 in the Carpathians, 12, in the Carpathian Foredeep, 43 in the Polish Lowland, and 2 in the Polish economic zone of the Baltic Sea. Oil resources in the Carpathians and Carpathian Foredeep are depleting. Currently, the most important oil fields are located in the Polish Lowland. Resources in this region account for $73.5 \%$ of all Polish oil resources, while resources in the Polish economic zone of the Baltic Sea account for 19.7\% (as of December 31, 2016). Oil fields in the Polish Lowland can be found in the Permian, Carbon and Cambrian formations. The developed fields account for $96 \%$ of the resources.

The production of oil in Poland in the years 2005-2017 is presented in Fig 2.The production is limited and covers approximately $4 \%$ of the domestic consumption. Crude oil is almost entirely consumed by refineries [6]. In 2005, the production of oil amounted to 850.000 tons to decrease to a level below 600.000 tons. In 2013, a significant increase in production, to the level of 961 thousand tons, was reported. The production of crude oil from the Baltic Sea is carried out by LOTOS Petrobaltic, which currently has seven concessions for exploration and extraction of hydrocarbons in the Polish economic zone of the Baltic Sea. The company has four concessions for the production in the following offshore fields: B3 (the currently exploited one), B8, B4, and B6 (licenses valid until 20312032) [7]. The extraction of oil on land is carried out by the PGNiG. In 2016, the share of oil in primary energy acquisition in Poland amounted to $1.5 \%$. The production of crude oil in Poland amounted to 1.0 million tons in 2016 and covered $4 \%$ of the consumption, which decreased by $1 \%$ compared to the previous year and amounted to 25.8 million tons [6].

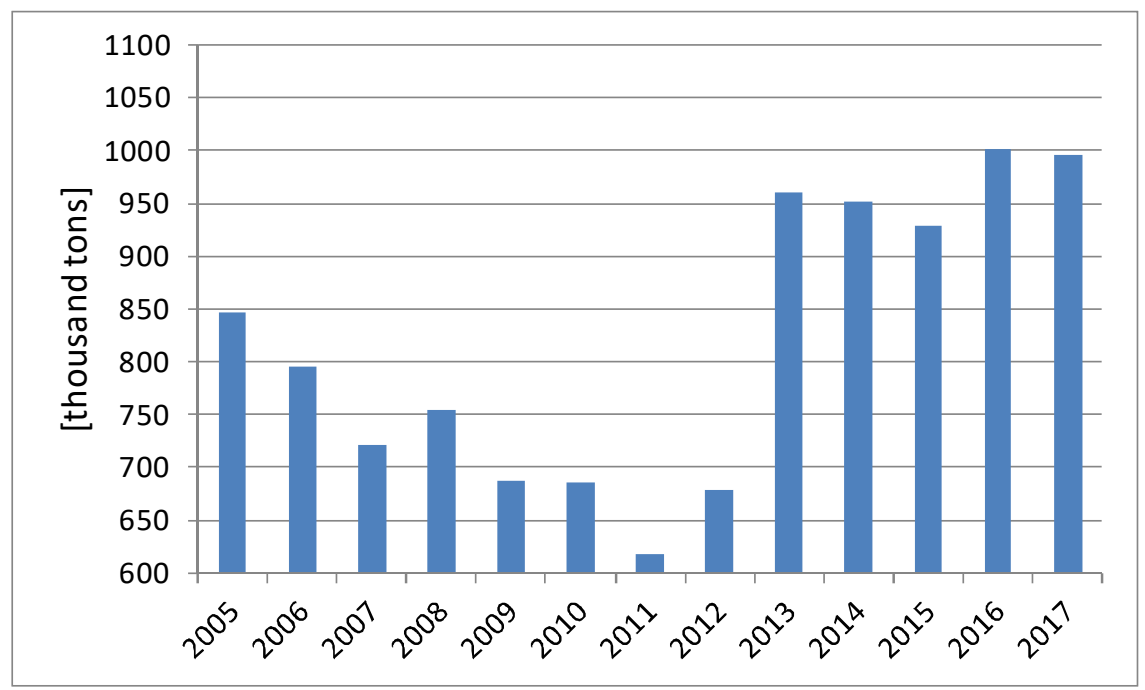

Fig. 2. Oil production in Poland in the years 2005-2017 Source: own study based on [6, 8] 
Oil imports to Poland in the years 2005-2017 are presented in Fig. 3. For years, crude oil is imported mainly from the East. In 2015, crude oil from Russia accounted for $81 \%$ of the total crude oil imported by Polish refineries [4]. The rest was supplied from Saudi Arabia, Iraq, Iran, and, in small quantities, Azerbaijan, Lithuania, Kazakhstan, Nigeria, and Norway. Part of the oil was produced in Polish fields. In 2017, imports from Azerbaijan and Nigeria were abandoned; instead, crude oil from USA, Denmark, and Canada was imported. The share of Russian oil declined at that time to $77.2 \%$. This was due to the increase in imports from Saudi Arabia, Norway, and Kazakhstan [9].

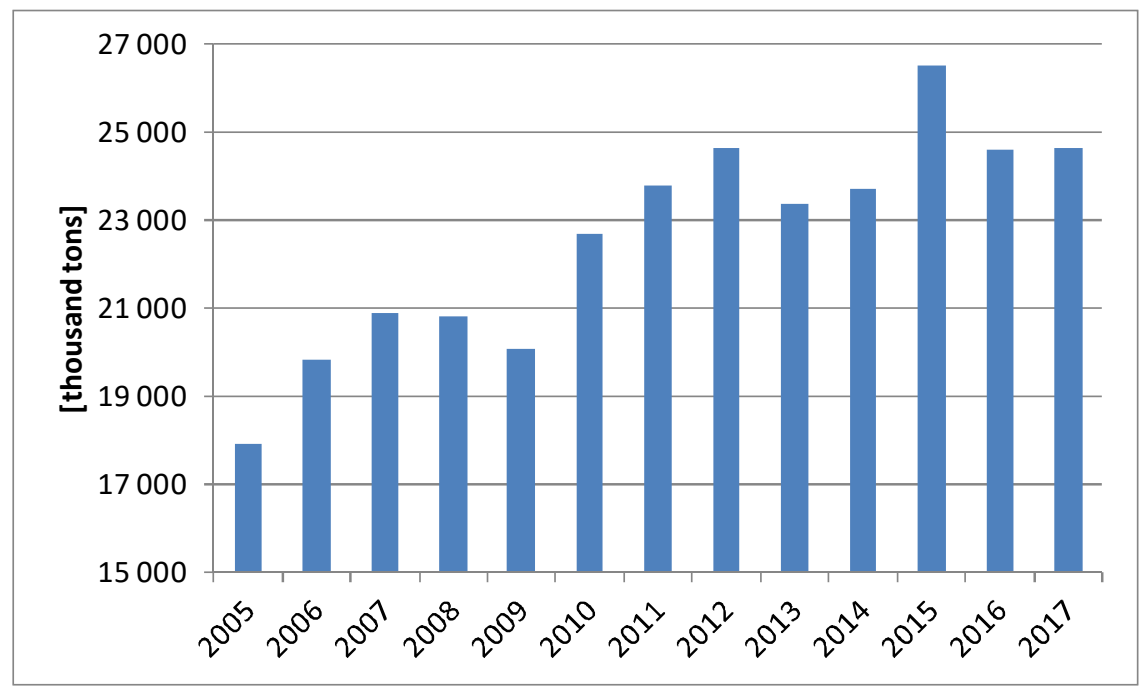

Fig. 3. Import of crude oil to Poland in the years 2005-2017 Source: own work based on [6, 8]

The basic type of oil processed in Poland is REBCO oil. This is due to long term contracts for oil pipeline supplies and the technological adaptation of Polish refineries to this type of crude oil. Polish refineries process British, Norwegian, and Iraqi crude oil. In addition, the LOTOS group uses crude oil obtained from the Baltic Sea, while PKN Orlen uses the domestic crude oil. Fortunately, from the point of view of energy security, Polish refineries can quickly move to other types of crude oil imported via the Northern Port in Gdansk. About 20 million tons of oil is imported via pipeline from the East, while about 4 million tons is provided by Naftoport. Pipelines supplying crude oil to Poland are operated by PERN. The pipeline consists of three sections: the East, West and the Pomeranian. The eastern section consists of two lines with a length $233 \mathrm{~km}$ and a capacity of 42 million tons of oil per year. Because of the crucial importance for the Polish economy, a third line is built since the year 2002. The western pipeline is used to transport oil to Germany and is $416 \mathrm{~km}$ long. It consists of two lines with a capacity of 27 million tons of oil per year.

The storage of oil is closely linked with the PERN pipeline system. The PERN Company owns, including crude oil terminal in Gdańsk, four storage depots [4]:

- The Adamowo Depot with a storage capacity of about 770 thousand $\mathrm{m}^{3}$ (15 storage tanks),

-The Miszewko Strzałkowskie Depot; twenty-nine storage tanks with a capacity of about 1464 thousand $\mathrm{m}^{3}$,

-The Gdańsk Depot - eighteen storage tanks with a capacity of about 900 thousand $\mathrm{m}^{3}$,

-The Gdańsk crude oil terminal - six storage tanks with a total capacity of $375000 \mathrm{~m} 3$. 
The PERN group also has pipelines for transporting gasoline, diesel, and heating oil to storage depots.

The most important investment related to the energy security in the field of liquid fuels is the commissioning of the Gdańsk crude oil terminal (8 April 2018). The investment cost was PLN 412 million. The target storage capacity of the oil Terminal will be 703 thousand $\mathrm{m}^{3}$.

The oil consumption in the years 2005-2017 is presented in Fig. 4. The oil consumption in Poland has been growing for years. This was due to the development of the automotive industry and the overall economic development of the country. In 2005, the consumption amounted to just over 18 million tons, but in the following year it has exceeded 20 million tons. The largest increases in consumption were recorded in the years 2009-2012 and in 2015. In the years 2013 and 2014, a slight decrease in consumption has been reported. The situation in the coming years will depend on many economic and political factors.

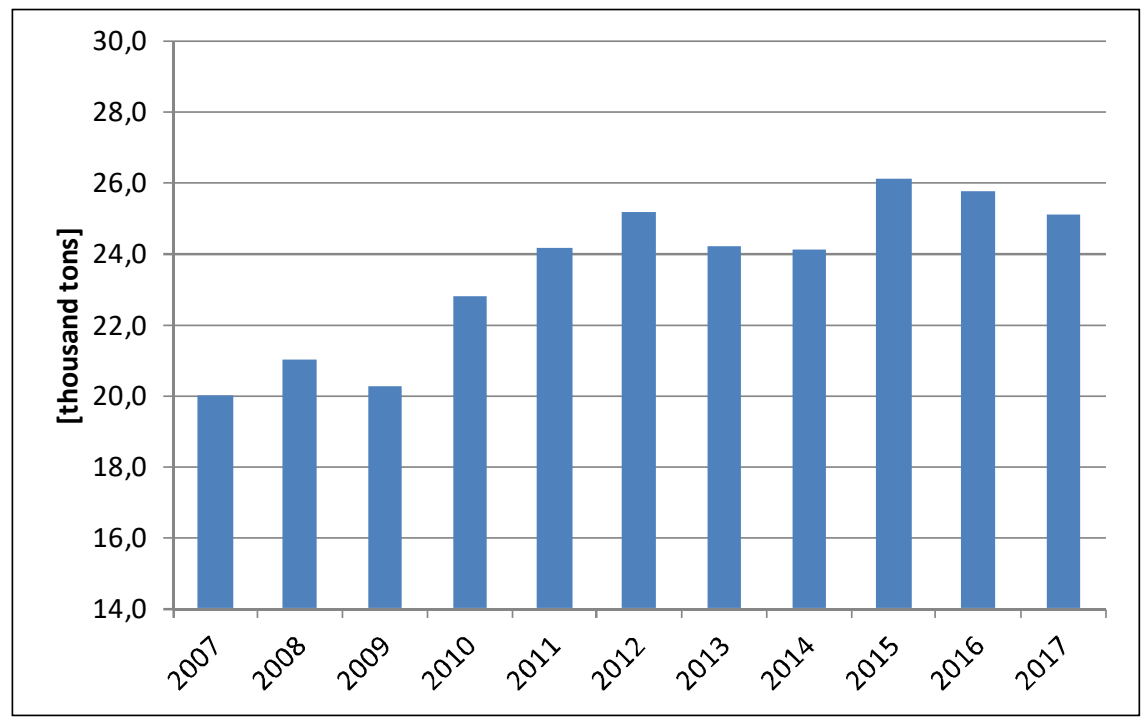

Fig. 4. Oil consumption in Poland in the years 2005-2017 Source: own work based on [6,8]

\section{The impact of global implications on the domestic crude oil market}

In recent years, the security of oil supplies to Poland is undoubtedly increasing. The increasing use of Naftoport (34.3\% of the domestic refinery throughput in 2017), and reduced pipeline imports demonstrate the increasing flexibility of supply and allow Polish refiners to acquire a very valuable experience in international markets [10]. In addition, seaborne transportation makes it easier to develop oil blends for refineries, depending on the expected yields of finished products. However, this does not change in any way the fact that Poland is dependent on global price trends and factors related to the supply of crude oil in world markets. According to the International Energy Agency (IEA), releasing monthly oil market report for nearly 20 years, by 2023 the world's oil demand will rise by $6.9 \mathrm{mb} / \mathrm{d}$ (350 million tons per year) to the level of $104.7 \mathrm{mb} / \mathrm{d}$ (5.16 billion tons per year), with Asia-Pacific and the Middle East accounting for $60 \%$ and $15 \%$ of the world's crude demand, respectively [11]. With data for almost three quarters of the current year, it can be stated that in 2018 this growth will be $1.4 \mathrm{mb} / \mathrm{d}$ and will exceeds the magical limit of 
consumption at the level of $100 \mathrm{mb} / \mathrm{d}$ (14 million tons per day) at the beginning of 2019 . For comparison purposes, the limit of $90 \mathrm{mb} / \mathrm{d}$ was exceeded in mid-2012. This means that over the last 6 years the world consumption has increased by 500 million tons per year despite the technological measures aimed at reducing oil consumption [12]. In the same period, global analytical centers have departed from peak oil forecasting, the moment from which the availability of raw material will only decrease. Today it is well known that forecasting the oil production is subject to the risk of underestimating - especially in the context of the U.S. oil shale boom. The U.S. Light Tight Oil (LTO) changes everything in the oil market: in the next three years, $80 \%$ of the global demand will be met by the United States alone, and by the end of 2018 The U.S. oil production can surpass Saudi Arabia and equal Russia. Two basic concerns about the development of the oil markets in the past year included the uncertainty about the impact of low oil prices on LTO production and the level of investments in the upstream sector after the slowdown of 2015-2016. The situation with the development of the LTO sector in the United States is now explained: the LTO sector is resilient to low oil prices. While in 2013 the LTO production was unprofitable below 75 USD/barrel, today this level fluctuates around 40 USD. By 2023, The U.S. oil production will increase by $3.7 \mathrm{mb} / \mathrm{d}$ ( $57 \%$ of the global production increase), reaching almost 17 $\mathrm{mb} / \mathrm{d}$. Given the current prices exceeding USD 80/barrel, further increases are expected. The market seems to anticipate the problems of the coming months, when the tightening of supply can be significant. The U.S. sanctions on Iran will be introduced on November 4, 2018, but the tanker movements from Iran, as observed by the IEA, are already in decline, indicating that exports from this country have already been reduced by $0.5 \mathrm{mb} / \mathrm{d}$. Keeping in mind that during the last round of sanctions crude oil exports fell by $1.2 \mathrm{mb} / \mathrm{d}$ in 2012 , the buyers distance themselves from Iran.

The second significant and growing problem of the oil market is Venezuela. The production at the level of $1.24 \mathrm{mb} / \mathrm{d}$ is the lowest in the last 60 years. In addition, the IEA expects that by the end of the year the production will decrease to $1 \mathrm{mb} / \mathrm{d}$. Therefore, the world supply situation is considered bad.

During the OPEC meeting on September 23, 2018, Both Russia and Saudi Arabia do not have announced production increases in the near future, which has led to an increase in oil prices. However, the United States with its huge extraction cannot improve the situation in the world market at the moment - the expanded export capabilities of U.S. ports won't be able to improve the worldwide supply situation before the end of 2019. These limitations mean that the U.S. production in the next several months will be high, but won't be confirmed by export figures. Taking into account inventories in the OECD countries, which are lower than the five-year average by as much as 50 million barrels of crude oil, a huge increase in air traffic, especially in India (20\%) and China (15\%), and an insignificant reduction of the demand for motor fuel (in the connection with the development of electric cars), the constantly growing demand for oil worldwide may lead to record prices. The largest oil trading companies claim to exceed the USD 100/barrel barrier as early as at the end of 2018 .

Another risk factor for the supply of crude oil is the global investment in conventional mining, especially in the offshore sector. After the dramatic decreases in investments by $25 \%$ in 2015 , and $26 \%$ in 2016, 2017 year brought significant changes, and the first 8 months of 2018, also does not give the certainty of change trend. This may be the greatest threat to meet the future demand after 2020, and the biggest factor in price pressures. Due to the depletion of oil fields, at least $3 \mathrm{mb} / \mathrm{d}$ of new capacity must be added each year (the entire annual production in the North Sea), while the production needs to be increased to meet the expected increase in demand. This means that the cumulative gain in production until 2023 must be $20.4 \mathrm{mb} / \mathrm{d}$ ( 1 billion tons, equivalent to 40 years of domestic (Polish) consumption). Meanwhile, the year 2017 was a record low when it comes to exploration of 
new oil fields - only 4 billion barrels in the new fields have been discovered worldwide, the lowest amount since 1930. The year 2019 may therefore be difficult for oil markets. The significant involvement of financial institutions in commodity markets, especially oil market, is the reason why the raw material prices are driven not only by pure market forces and can strongly influence inflation in the country, resulting in higher product prices and lower profitability of industries dependent on fuel prices, even though the supply situation of Poland does not change. Such a complicated situation on the crude oil market is beneficial for OECD countries, including Poland; the import dependence of these countries is the lowest in 27 years, which in theory significantly increases the energy security and reduces the impact of market instability on the economies of the member states.

In addition, taking into account the general tightening of the oil supply, the production capacity of OPEC countries in 2018 will decrease for the first time since 2011. Meanwhile, any production increases after 2019 depend on the production in the Neutral Zone, (the disputed area jointly administered by Kuwait and Saudi Arabia). The investments in other countries in the Middle East countries will not change this situation; they are just the result of the expected greater domestic demand (Saudi Arabia consumes e.g. up to 25 million tons of crude oil per year only to meet energy needs associated with air conditioning). After 2020, markets will continue to tighten and there may be problems with the supply - the U.S. production of light tight oil might slow down, which may lead to an increase in demand. Therefore, IEA urges countries to make investment decisions in order to avoid supply disruptions. The spare refining capacity in 2023 will be only $2.2 \%$ of the supply and will be the lowest since 2007, when prices began to rise to historical levels. The problem is the erosion of producers' confidence in the market situation after the crisis of 2015-2016; currently, the largest enterprises favor projects with short investment cycles such as LTO in the U.S. Meanwhile, smaller companies have not yet started to make profits after the mentioned crisis.

There are two additional risk factors that are the result of changes in the markets over the last year: excess oil inventories have declined and today they are close to the five-year average (at the end of 2017 they were only slightly higher than in 2013). In addition, the world refining sector will struggle with the excess processing capacity for two reasons: firstly, some of the importing countries, especially in South-East Asia, build refineries to avoid dependence on the supply of finished products; secondly - oil producers invest in refining capacities to use their own raw material. By 2023 , additional $7.7 \mathrm{mg} / \mathrm{d}$ of refining capacities will be developed; $2 \mathrm{mg} / \mathrm{d}$ will be developed in the Middle East alone. In 2023, the spare refining capacity will amount to $20 \mathrm{mg} / \mathrm{d}$, which will not remain without impact on the margins (in Europe, a decrease in the average use of refineries, from $88 \%$ in 2017 to $83 \%$ in 2023 , is expected). By 2023, alternative fuels will replace only about $0.5 \mathrm{mg} / \mathrm{d}$ of motor and diesel fuels. Electric cars will account for only a small part of this volume; instead, electric buses, LNG trucks, and CNG cars will have a dominant share in the market.

\section{Conclusions}

As indicated in the article, Poland is relatively safe when it comes to crude oil supplies thanks to two stable import routes of imports, but world supply disruptions and price spikes will clearly have a significant impact on Poland. Taking into account strong market competition, Polish refineries will have to prepare for periods of instability. Nevertheless, Poland has a good and proven mechanism to intervene in the form of large, and still growing, storage capacities plus oil stocks equaling more than 110 days of net imports. It is clearly visible that while market factors can be predicted and taken into account in short-term forecasting, political actions and regional tensions are usually hard to 
predict and can change the picture significantly. Unilateral US sanctions on Iran are a good example of this. In conclusion, both significant increases in oil prices and regional problems with its availability are possible in the near future, but the most important thing is how the producers will respond to permanent supply problems after 2020. This should be a signal for Polish companies active in the offshore sector that the acquisition of cheap oil fields in politically stable regions may not only be profitable but also significantly contribute to the stability of the Polish oil market.

This study was funded by Statutory Research of the AGH University of Science and Technology No. 11.11.210.375 and 11.11.190.555.

\section{References}

1. Outlook 2017 - World Energy Outlook 2017. International Energy Agency. 2017.

2. The Energy Policy of Poland until 2030. The document adopted by the Council of Ministers on 10 November 2009.

3. The draft Energy Policy of Poland until 2050. The Ministry of Development. Warsaw, Poland, August 2015.

4. POPiHN 2016 - Industry and trade of petroleum. Annual Reports for the years 2016 and 2017. Polish Organization of Oil Industry and Trade.

5. The balance of mineral resources deposits in Poland as of 31.12.2017. The Polish Geological Institute - National Research Institute Warsaw 2018.

6. Fuel and energy economy in the years 2005-2016 (Gospodarka paliwowo-energetyczna w latach 2005 - 2016). Statistics Poland. Warsaw. Issues from 2007 - 2017.

7. Nafta Polska (http://www.nafta-polska.pl/) (accessed 11.04.2016).

8. Energy situation in Poland: national energy balance. IV quarter of 2017. No. 4 (110). Agencja Rynku Energii (ARE S.A.)

9. POPiHN 2017 - Industry and trade of petroleum. Annual Reports for the years 2016 and 2017. Polish Organization of Oil Industry and Trade.

10. The Ministry of Energy 2018: Oil and fuel market - statistical data.

11. IEA 2018 - Market Report Series, Oil 2018, pp. 16.

12. IEA 2012 - Medium-Term Oil Market Report 2012, pp. 35. 